\author{
dr Dariusz KACPRZAK \\ Wydział Informatyki, Politechnika Białostocka \\ e-mail: d.kacprzak@pb.edu.pl
}

DOI: $10.15290 /$ ose.2017.03.87.08

\title{
ZASTOSOWANIE SKIEROWANYCH LICZB ROZMYTYCH W MODELU RÓWNOWAGI RYNKOWEJ1
}

\begin{abstract}
Streszczenie
W pracy rozważono liniowy model równowagi rynkowej, w którym parametry są liczbami rzeczywistymi. W modelu tym zakłada się, że popyt i podaż zależą tylko od ceny, a czynniki pozacenowe są niezmienne. Jednak, by uzyskać bardziej realistyczny model, można uwzględnić wpływ czynników pozacenowych na popyt i podaż. W ten sposób otrzyma się model z rozmytymi parametrami, które mogą być reprezentowane za pomocą skierowanych liczb rozmytych. Aby wyznaczyć rozmytą równowagę rynkową tego modelu, należy rozwiązać rozmyty, liniowy układ równań.
\end{abstract}

Słowa kluczowe: podaż, popyt, równowaga rynkowa, skierowane liczby rozmyte

\section{APPLICATION OF ORDERED FUZZY NUMBERS TO MODELING OF MARKET EQUILIBRIUM}

\section{Summary}

The paper considers a linear model of market equilibrium in which real numbers are taken as parameters. In the model, it is assumed that demand and supply depend only on price, while other (nonprice related) determinants do not change. However, to get a more realistic model, the author takes into account the impact of other (non-price related) determinants on demand and supply. In this way, a model with fuzzy parameters is obtained, which can be represented by means of ordered fuzzy numbers. In order to determine the fuzzy market equilibrium of such a model, a fuzzy linear system of equations must be solved.

Key words: demand, supply, market equilibrium, ordered fuzzy numbers

JEL: C02, C20, C65

\footnotetext{
${ }^{1}$ Badania zostały zrealizowane w ramach pracy $\mathrm{nr}$ S/WI/1/2016 i sfinansowane ze środków na naukę MNiSW.
} 


\section{Wstęp}

W pracy przedstawiono matematyczny model sytuacji ekonomicznej, nazywanej równowagą rynkową. Jest to taki stan gospodarki, w którym popyt na dobra i usługi jest równoważony podażą tych dóbr i usług. Chcąc zapewnić przejrzystość i prostotę modelu (częściowej) równowagi, często przyjmuje się, że funkcje popytu i podaży są liniowe o rzeczywistych parametrach oraz korzysta się z klauzuli ceterisparibus, która zakłada niezmienność determinantów pozacenowych. Jednak, aby model był bliższy rzeczywistemu obrazowi rynku, można uwzględnić wpływ czynników pozacenowych na parametry funkcji popytu i podaży. W ten sposób osiaga się model równowagi o parametrach rozmytych.

Celem pracy jest prezentacja modelu skierowanych liczb rozmytych w aspekcie możliwości zastosowania go w modelowaniu ekonomicznym. Wykorzystano go w modelu równowagi częściowej, w którym parametry przedstawiono za pomocą skierowanych liczb rozmytych. Działania arytmetyczne na tych liczbach sa zbliżone do działań na liczbach rzeczywistych. Dodatkowo, istnienie elementów przeciwnych względem dodawania i odwrotnych względem mnożenia pozwala na rozwiązywanie układów równań liniowych o rozmytych współczynnikach.

W literaturze można znaleźć szereg prac, które stosują model skierowanych liczb rozmytych w modelach ekonomicznych. Modelem tym posłużono się m.in.: do prezentacji przychodu i kosztu [Kosiński i in. 2009; Kacprzak, 2010; 2012a], w modelu Leontiewa [Kacprzak, 2008; 2010; 2017], do prezentacji cen akcji [Kacprzak, 2012b; Kacprzak i in. 2013; Marszałek, Burczyński, 2013], do prezentacji cen i dynamiki ich zmian [Kacprzak, 2014] czy do ustalania ekonomicznej wielkości dostawy [Kacprzak, Kosiński, 2014; Sobol i in. 2015]. Ważnym zastosowaniem modelu skierowanych liczb rozmytych jest użycie go w wielokryterialnych metodach wspomagana decyzji. Badania w tym zakresie zostały zapoczątkowane przez Roszkowską i Kacprzaka [Roszkowska, Kacprzak, 2016; Kacprzak, 2017], następnie wykorzystane do rozwiazzania praktycznego problemy sterowania linią produkcyjna [Rudnik, Kacprzak, 2017]. Wspomniane wyżej zastosowania korzystają ze skierowania jako dodatkowej informacji oraz arytmetykę zbliżoną do arytmetyki liczb rzeczywistych, czego nie posiadały wcześniejsze modele liczb rozmytych.

Artykuł składa się z siedmiu części. W drugiej krótko zaprezentowano liniowy model równowagi rynkowej o parametrach rzeczywistych, w następnej przedstawiono argumenty przemawiające za zastapieniem w tym modelu parametrów rzeczywistych liczbami rozmytymi. Część czwartą i piąta poświęcono prezentacji modelu skierowanych liczb rozmytych i użyciu tych liczb jako parametrów modelu równowagi. Ostatnią część stanowi przykład numeryczny i podsumowanie.

\section{Liniowy model równowagi rynkowej}

Popyt na dobro to przypadająca na jednostkę czasu wielkość zapotrzebowania odpowiadająca różnym cenom tego dobra. Zależy on od wielu zmiennych, z których podstawową (wynikającą z określenia) jest cena. Do pozacenowych determinantów popytu można zaliczyć:

- dochody nabywców, 
- ceny dóbr komplementarnych i substytucyjnych,

- oczekiwania dotyczące sytuacji rynkowej,

- gusty i preferencje nabywców,

- przewidywane zmiany cen dobra,

- zmiany liczby i struktury ludności [Milewski, Kwiatkowski, 2005, s. 46].

Z kolei, podaż dobra to ilość dobra w jednostce czasu oferowana na rynku przy różnych wysokościach ceny. Podobnie jak w przypadku popytu, podaż jest również funkcją wielu zmiennych, z których główną jest także cena. Natomiast do pozacenowych determinantów podaży można zaliczyć:

- koszty wytwarzania,

- rentowność produkcji dóbr substytucyjnych,

- przewidywane zmiany cen dobra,

- $\quad$ wypadki losowe i czynniki naturalne (przy pewnych rodzajach produkcji) [Milewski, Kwiatkowski, 2005, s. 51].

W ekonomii powszechnie korzysta się z klauzuli ceteris paribus. Pozwala ona badać np. zależność między popytem a ceną oraz podażą a cena, jak również równowagę rynkowa, zakładając, że czynniki pozacenowe nie ulegają zmianie. W pozycjach poświęconych ekonomii matematycznej wspomniany model równowagi rynkowej często jest przedstawiany za pomocą funkcji liniowych, tzw. model liniowy [Chaing, 1994, s. 48; Gawinecki, 2000, s. 88]. Zaletą takiego podejścia jest niewątpliwie przejrzystość i prostota.

W celu zaprezentowania liniowego modelu równowagi rynkowej, zakłada się, że na rynku (wyizolowanym) znajduje się tylko jedno dobro konsumpcyjne. Oznacza to, że w modelu równowagi wystarczy uwzględnić trzy zmienne, tj.:

- $P$ - cenę dobra,

- $Q_{d}$ - wielkość popytu na dobro,

- $Q_{s}$ - wielkość podaży dobra.

Ponadto, zakłada się, opierając się na obserwacji rynku, że popyt jest malejącą liniową funkcją ceny, tzn. ma postać (rysunek 1.)2:

$$
Q_{d}=a-b P,
$$

natomiast podaż jest rosnącą liniową funkcją ceny, tzn. ma postać (rysunek 1.):

$$
Q_{s}=-c+d P,
$$

gdzie parametry $a, b, c, d \in \mathbb{R}_{+}$. Dodatkowo przyjmuje się, że podaż nie występuje do chwili, kiedy cena nie przekroczy określonego dodatniego poziomu (z równania (2) wynika, że jest on równy $c / d$ ). Równowaga na modelowanym rynku zachodzi wówczas, gdy:

$$
Q_{d}=Q_{s}
$$

Biorąc pod uwagę równania (1)-(3), równowaga rynkowa jest osiagnięta, gdy cena ma wartość:

\footnotetext{
${ }^{2} \mathrm{Na}$ rysunku 1. oznaczenia osi nie są zgodne z konwencją matematyczna, tzn. oś pozioma oznacza cenę, a oś pionowa opisuje wielkość popytu i podaż, ponieważ zastosowano konwencję przyjętą w podręcznikach do ekonomii. Pozostałe rysunki również utrzymano w tej konwencji.
} 


$$
\bar{P}=\frac{a+c}{b+d},
$$

a odpowiadająca jej wielkość równowagi $\bar{Q}\left(\bar{Q}=Q_{d}=Q_{s}\right)$ wynosi:

$$
\bar{Q}=\frac{a d-b c}{b+d} .
$$

Z (5) wynika, że aby $\bar{Q}>0$ (punkt przecięcia musi znajdować się powyżej osi poziomej) parametry funkcji liniowych (1) i (2) muszą spełniać warunek:

$$
a d>b c \text {. }
$$

RYSUNEK 1.

Ilustracja graficzna liniowej funkcji popytu (1), liniowej funkcji podaży (2) oraz równowagi rynkowej

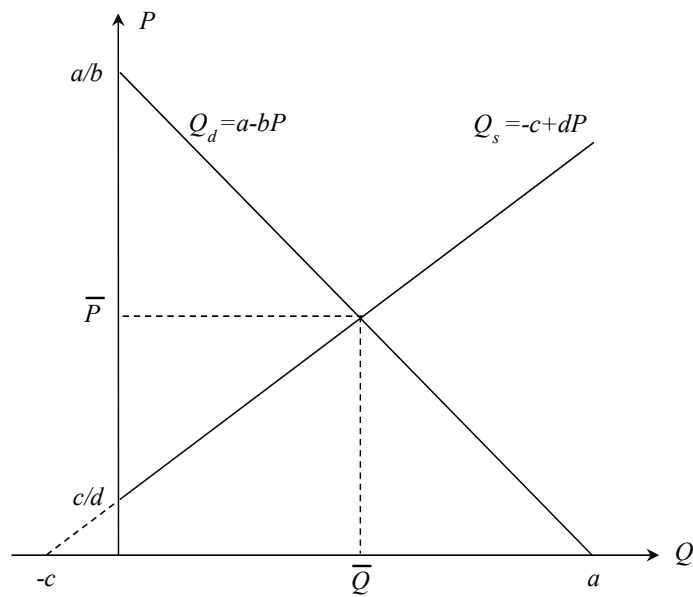

Źródło: opracowanie własne na podstawie: [Chiang, 1994, s. 49].

\section{Liniowy model równowagi rynkowej o rozmytych parametrach}

W uproszczonym liniowym modelu równowagi rynkowej (1)-(3) założono, że jego parametry, tzn. $a, b, c$ i $d$ są rzeczywistymi liczbami dodatnimi. Jednak zwrócono uwagę na to, że aby model równowagi rynkowej był bliższy rzeczywistości, a jednocześnie dalej pozostał przejrzysty i prosty, te parametry moga być opisane za pomocą liczb rozmytych, co wynika z kilku obserwacji rynku.

1. Istnienie czynników pozacenowych.

Na rzeczywistym rynku, jak wspomniano w części 1., popyt zależy od różnych czynników pozacenowych. Zmiana któregoś z nich powoduje przesunięcie funkcji popytu. W przypadku liniowej funkcji popytu znajduje to odzwierciedlenie w zmianie wartości wyrazu wolnego, czyli elementu $a$ w liniowej funkcji popytu (1).

2. Elastyczność cenowa funkcji popytu. 
Elastyczność cenowa popytu mierzy procentową (względna) zmianę zapotrzebowania w reakcji na procentowa (względna) zmianę ceny. Do czynników wpływających na jej wielkość można zaliczyć m.in. ilość i bliskość substytutów oraz procentowy udział dobra w wydatkach konsumenta [Sloman, 2001, s. 63]. Korzystając z pochodnej funkcji, można pokazać, że elastyczność cenowa liniowej funkcji popytu zależy wprost proporcjonalnie od współczynnika kierunkowego. Oznacza to, że czynniki pozacenowe oddziałują na zmianę współczynnika kierunkowego $c$ w liniowej funkcji popytu (1).

\section{Stosowanie określeń nieprecyzyjnych i niejednoznacznych w ekonomii.}

Dane do konstrukcji funkcji popytu mogą pochodzić z wielorakich źródeł, m.in. w wyniku ankietowania konsumentów. Ci z kolei mogą stosować, co jest częste w ekonomii, określenia nieprecyzyjne i niejednoznaczne. Na przykład konsumenci, udzielając odpowiedzi na pytanie o wielkość zapotrzebowania na dobro, gdy jego cena wzrośnie o jednostkę, moga posługiwać się określeniami typu „około 10” czy „w przybliżeniu 10”, zamiast precyzyjną wartościa. W przypadku liniowej funkcji popytu, wykorzystując interpretację matematyczną czy ekonometryczna, współczynnik kierunkowy wyznacza wielkość spadku popytu wywołanego wzrostem ceny o jednostkę, co oznacza, że takie nieprecyzyjne informacje znajdą odzwierciedlenie we współczynniku kierunkowym $C$ w liniowej funkcji popytu (1).

Analogiczne uwagi można sformułować w stosunku do liniowej funkcji podaży. Wspomniane obserwacje rzeczywistego rynku uzasadniają użycie liczb rozmytych do opisu paramentów modelu równowagi rynkowej.

\section{Skierowane liczby rozmyte}

W 1965 roku w czasopiśmie „Information and Control” ukazała się praca Lotfi A. Zadeha pod tytułem: Fu₹zy Sets [Zadeh, 1965], w której autor wprowadził pojęcie zbioru rozmytego. Liczba rozmyta to wypukły, normalny zbiór rozmyty, określony na uniwersum liczb rzeczywistych, którego funkcja przynależności jest kawałkami ciagła. Zbiory i liczby rozmyte dały możliwość matematycznego modelowania wielkości nieprecyzyjnych, niepewnych czy też wyrażonych w postaci opisowej (lingwistycznych). Znalazło to szerokie zastosowanie praktyczne, $\mathrm{m}$. in. w zagadnieniach związanych ze sterowaniem i podejmowaniem decyzji.

Podstawowe działania arytmetyczne na liczbach rozmytych opierają się na zasadzie rozszerzania i są dość skomplikowane. Wymagają wykonania wielu operacji zarówno na stopniach przynależności, jak i na elementach nośników. Dodatkowo zastosowania praktyczne liczb rozmytych pokazuja, że ich funkcje przynależności zazwyczaj nie sa dyskretne, ale ciąłłe, a także mają stosunkowo regularny kształt, często w postaci: trójkąta, trapezu, krzywej Gaussa itp. Oznacza to, że nie trzeba podawać stopni przynależności dla wszystkich elementów nośnika, a jedynie kilka parametrów, które jednoznacznie określają regularne funkcje przynależności. Powyższe spostrzeżenia sprawiły, że Dubois i Prade [Dubois, Prade, 1980, s. 53] zaproponowali specjalną postać liczb roz- 
mytych, nazywaną reprezentacją typu $L R$, która znacznie poprawia efektywność wykonywanych działań arytmetycznych. Jednocześnie pokazali oni, że dokładne wzory można uzyskać tylko dla dodawania i odejmowania, natomiast w przypadku mnożenia i dzielenia przedstawiono formuły przybliżone.

Model liczb rozmytych, zaproponowany przez Zadeha, a także jego późniejsza modyfikacja, tzw. model $L R$, posiadają kilka słabości, które ograniczają ich zastosowanie w niektórych dziedzinach, np. w modelowaniu ekonomicznym. Niedoskonałości te wynikaja przede wszystkim z określenia działań arytmetycznych na tych liczbach. Powodują one powiększanie nośnika (niezależnie, czy liczby rozmyte dodajemy, czy odejmujemy), jak również brak elementów przeciwnych względem dodawania i odwrotnych w stosunku do mnożenia. Skutkuje to brakiem możliwości rozwiązywania, w ogólnym przypadku, prostych równań: $A+X=C$ oraz $A \cdot X=C$, gdzie $A$ i $C$ są ustalonymi liczbami rozmytymi, ponieważ $A+X+(-A) \neq X$ i $A \cdot X \cdot A^{-1} \neq X$. Dodatkowo, rozwiązanie równania $A+X=C$ nie istnieje, jeżeli nośnik liczby $A$ jest szerszy, niż nośnik liczby $C$.

Wspomnianych powyżej ograniczeń jest pozbawiony model skierowanych liczb rozmytych (Ordered Fuгzy Numbers - OFN)33. Został on zaproponowany w 2002 roku przez Kosińskiego, Prokopowicza i Ślęzaka [Kosiński i in. 2002; 2003; Kosiński, Prokopowicz, 2004]. Arytmetyka działań w tym modelu jest analogiczna do działań na liczbach rzeczywistych, które stają się szczególnym przypadkiem OFN.

Skierowaną liczbą rozmytą $A$ nazywamy uporządkowaną parę funkcji ciagłych:

$$
A=\left(f_{A}, g_{A}\right) \text {, }
$$

gdzie

$$
f_{A}, g_{A}:[0,1] \rightarrow \mathbb{R} .
$$

Poszczególne funkcje skierowanej liczby rozmytej nazywamy odpowiednio: $f_{A}-$ częścią wznosząca $(U P), g_{A}-$ częścią opadająca $(D O W N$ ) (rysunek 2a). Ponieważ obie te funkcje są ciagłe, to ich obrazy są ograniczonymi przedziałami odpowiednio $U P_{A}$ i $D O W N_{A}$, których granice oznaczamy następująco: $U P_{A}=\left(f_{A}(0), f_{A}(1)\right)$ oraz $D O W N_{A}=\left(g_{A}(1), g_{A}(0)\right)$. Na rysunku 2a przedstawiono ilustrację graficzną skierowanej liczby rozmytej, gdzie $y$ jest argumentem funkcji $f_{A} \mathrm{i} g_{A}$, natomiast $x$ wartością tych funkcji. Jeżeli funkcje $f_{A} \mathrm{i} g_{A}$ są ściśle monotoniczne, istnieją do nich funkcje odwrotne $f_{A}^{-1}$ i $g_{A}^{-1}$, określone na odpowiednich przedziałach $U P_{A}$ i $D O W N_{A}$ (rysunek $2 \mathrm{~b}$ ). Do zbiorów $U P_{A}$ i $D O W N_{A}$ dodajemy na przedziale $\left[f_{A}(1), g_{A}(1)\right]$ (przedział ten może być jednoelementowy) funkcję stała (CONST) równą 1 (warunek normalności). Wówczas zbiór $U P_{A} \cup\left[f_{A}(1), g_{A}(1)\right] \cup D O W N_{A}$ tworzy jeden przedział (nośnik liczby $A$ ). Pozwala to określić funkcję przynależności $\mu_{A}$ skierowanej liczby rozmytej $A$ w następujący sposób [Kacprzak, 2008; 2010]:

\footnotetext{
${ }^{3}$ Po śmierci prof. Kosińskiego, aby upamiętnić i uhonorować jego imię, termin Ordered Fuzzy Numbers często zastępowano określeniem Kosinski Fuzzy Numbers [Prokopowicz, Pedrycz, 2015].
} 


$$
\mu_{A}(x)=\left\{\begin{array}{ccc}
0 & \text { gdy } & x \notin\left[f_{A}(0), g_{A}(0)\right] \\
f_{A}^{-1}(x) & \text { gdy } & x \in U P_{A} \\
1 & \text { gdy } & x \in\left[f_{A}(1), g_{A}(1)\right] \\
g_{A}^{-1}(x) & \text { gdy } & x \in D O W N_{A}
\end{array}\right.
$$

RYSUNEK 2.

a) Przykładowa skierowana liczba rozmyta, b) Skierowana liczba rozmyta przedstawiona w sposób nawiązujący do wypukłych liczb rozmytych, c) Strzałka przedstawiająca porządek odwróconych funkcji i orientację OFN

a)

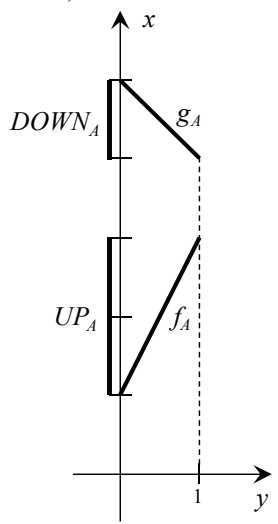

b)

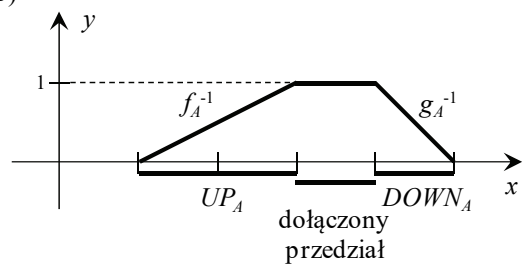

c)

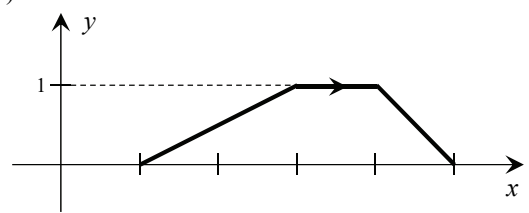

Źródło: [Kosiński i in. 2002].

Tak określone liczby rozmyte nawiązują do wypukłych liczb rozmytych (Convex Fuz:y Numbers - CFN), jednak są wyposażone w dodatkową własność zaznaczoną strzał$\mathrm{ka}$ - skierowanie (rysunek 2c).

Graficznie liczba $\left(f_{A}, g_{A}\right)$ nie różni się od liczby $\left(g_{A}, f_{A}\right)$, lecz w rzeczywistości są to dwie różne liczby, różniące się skierowaniem. Skierowanie pozwala na podzielenie zbioru skierowanych liczb rozmytych na dwie grupy: liczby o skierowaniu dodatnim, jeżeli skierowanie jest zgodne z osią $O x$ (rysunek 3a), liczby o skierowaniu ujemnym, jeżeli skierowanie jest przeciwne niż oś $O x$ (rysunek $3 \mathrm{~b}$ ).

RYSUNEK 3.

a) Skierowana liczba rozmyta $\left(\boldsymbol{f}_{A}, \boldsymbol{g}_{A}\right)$ o skierowaniu dodatnim, b) Skierowana liczba rozmyta $\left(g_{A}, f_{A}\right)$ o skierowaniu ujemnym

a)

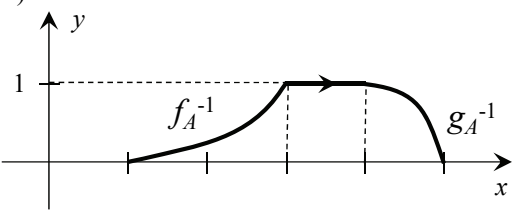

b)

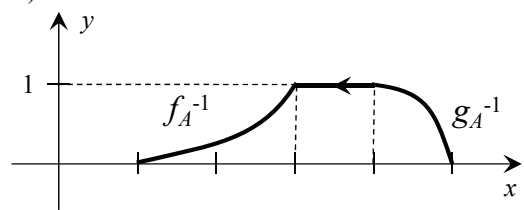

Źródło: opracowanie własne. 
Szczególnym przypadkiem skierowanych liczb rozmytych są liczby rzeczywiste. W modelu OFN są one utożsamiane z parą funkcji stałych. Dokładniej, liczba $r \in \mathbb{R}$ jest zapisywana jako skierowana liczba rozmyta postaci $r=\left(r^{*}, r^{*}\right)$, gdzie $r^{*}(y)=r$ dla $y \in[0,1]$.

Podstawowe działania arytmetyczne, czyli dodawanie $(+)$, odejmowanie $(-)$, mnożenie $(\times)$ i dzielenie $(/)$, na skierowanych liczbach rozmytych są określone następująco. Niech $A=\left(f_{A}, g_{A}\right)$ i $B=\left(f_{B}, g_{B}\right)$ będą skierowanymi liczbami rozmytymi, wówczas liczba $C=\left(f_{C}, g_{C}\right)$ jest wynikiem działania $* \in\{+,-, \times, /\}$ na liczbach: $A$ i $B(C=A * B)$, jeżeli:

$$
\forall y \in[0,1]\left[f_{C}(y)=f_{A}(y) * f_{B}(y) \text { i } g_{C}(y)=g_{A}(y) * g_{B}(y)\right] .
$$

Dodatkowo, w przypadku dzielenia musi być spełniony warunek, że $\forall y \in[0,1] f_{B}(y) \neq 0$ i $g_{B}(y) \neq 0$. Zbiór skierowanych liczb rozmytych z tak określonymi działaniami ma strukturę przestrzeni liniowo-topologicznej [Kosiński, Prokopowicz, 2004].

Warto w tym miejscu nadmienić, że wykonując działania arytmetyczne na skierowanych liczbach rozmytych, jako wynik można uzyskać tzw. liczby ,niewłaściwe” [Kosiński $i$ in. 2003], niebędące skierowanymi liczbami rozmytymi, których interpretacja jest trudna. Na przykład weźmy dwie skierowane liczby rozmyte $A=(1+2 s, 7-s)$ i $B=(6-s, 2+2 s)$, gdzie $s \in[0,1]$, wówczas ich suma $A+B=(7+s, 9+s)$, gdzie $s \in[0,1]$ jest niewłaściwą liczbą rozmytą (rysunek 4.).

RYSUNEK 4.

Dwie trapezowe skierowane liczby rozmyte $A$ i $B$ oraz „niewłaściwa” liczba będąca ich sumą $A+B$
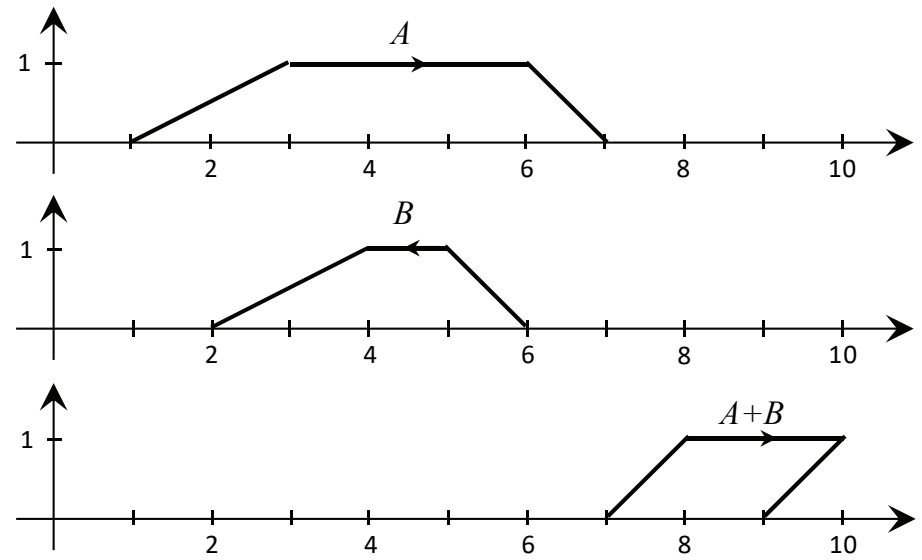

Źródło: opracowanie własne. 


\section{Skierowane liczby rozmyte w liniowym modelu równowagi rynkowej}

Skierowane liczby rozmyte, poza modelowaniem nieprecyzyjności (rozmytości), pozwalają również uwzględnić dodatkowy element (informację) obrazowany skierowaniem. Przyjmijmy, że rozmyte liniowe funkcje popytu (1) i podaż (2) maja postać:

$$
\begin{gathered}
Q_{d}=\tilde{a}-\tilde{b} P, \\
Q_{s}=-\tilde{c}+\tilde{d} P,
\end{gathered}
$$

gdzie parametry: $\tilde{a}, \tilde{b}, \tilde{c}$ i $\tilde{d}$ są reprezentowane za pomocą skierowanych liczb rozmytych. Biorąc pod uwagę skierowanie, otrzymamy $3^{4}=81$ różnych układów parametrów modelu (wliczając w to również parametry rzeczywiste). W pracy ograniczono się do układów, w których skierowanie będziemy interpretować przez pryzmat oczekiwań uczestników rynku w odniesieniu do ceny. Oznacza to, że wartość $f(0)$ będzie określała wielkość parametru najmniej oczekiwana (pożądana) przez konsumenta lub producenta, natomiast $g(0)$ wielkość parametru najbardziej oczekiwaną (pożądana). Korzystając $\mathrm{z}$ liniowej rozmytej funkcji popytu (10), mamy:

$$
Q_{d}=\tilde{a}-\tilde{b} P \Rightarrow P=\frac{\tilde{a}-Q_{d}}{\tilde{b}} .
$$

Warto zauważyć, że im niższa cena rynkowa, tym korzystniejsza sytuacja konsumenta (założyliśmy, że popyt jest malejąca liniową funkcją ceny). Z (12) widać, że wyraz wolny $\tilde{a}$ stoi w liczniku, co oznacza, że im mniejsza jego wartość, tym cena dobra jest niższa. Ponadto, współczynnik kierunkowy $\tilde{b}$ stoi w mianowniku, więc im wyższa jego wartość, tym cena dobra jest niższa. Sprawia to, że wyraz wolny a a powinien mieć skierowanie ujemne (rysunek 5 a, gdzie $\tilde{a}=\widetilde{40}$ ), natomiast współczynnik kierunkowy $\tilde{b}$ skierowanie dodatnie (rysunek 6 a, gdzie $\tilde{c}=\tilde{8}$ ). Odmiennie sytuacja wygląda ze strony producenta. Z (11) mamy:

$$
Q_{S}=-\tilde{c}+\tilde{d} P \Rightarrow P=\frac{\tilde{c}+Q_{S}}{\tilde{d}} .
$$

Producent jest zainteresowany ukształtowaniem się ceny na jak najwyższym poziomie (założyliśmy, że podaż jest rosnąca liniową funkcją ceny). Z (13) widać, że wyraz wolny $\tilde{c}$ powinien mieć skierowanie dodatnie (rysunek $5 \mathrm{~b}$, gdzie $\tilde{c}=\tilde{6}$ ), zaś współczynnik kierunkowy $\tilde{d}$ skierowanie ujemne (rysunek $6 \mathrm{~b}$, gdzie $\tilde{d}=\widetilde{20}$ ).

Korzystając z zależności (4)-(5) oraz rozmytej liniowej funkcji popytu (10) i z rozmytej liniowej funkcji podaży (11), otrzymujemy rozmytą równowagę rynkowa, przy której rozmyta cena ma postać:

$$
\bar{P}=\frac{\left(f_{a}, g_{a}\right)+\left(f_{c}, g_{c}\right)}{\left(f_{b}, g_{b}\right)+\left(f_{d}, g_{d}\right)}=\frac{\left(f_{a}+f_{c}, g_{a}+g_{c}\right)}{\left(f_{b}+f_{d}, g_{b}+g_{d}\right)},
$$

a odpowiadająca jej rozmyta wielkość równowagi $\bar{Q}\left(\bar{Q}=Q_{d}=Q_{S}\right)$ wyraża się następująco:

$$
\bar{Q}=\frac{\left(f_{a}, g_{a}\right)\left(f_{d}, g_{d}\right)-\left(f_{b}, g_{b}\right)\left(f_{c}, g_{c}\right)}{\left(f_{b}, g_{b}\right)+\left(f_{d}, g_{d}\right)}=\frac{\left(f_{a} f_{d}, g_{a} g_{d}\right)-\left(f_{b} f_{c}, g_{b} g_{c}\right)}{\left(f_{b}+f_{d}, g_{b}+g_{d}\right)} .
$$


RYSUNEK 5.

Skierowane liczby rozmyte reprezentujące wyraz wolny rozmytej liniowej funkcji: a) popytu (10), b) podaży (11)

a)

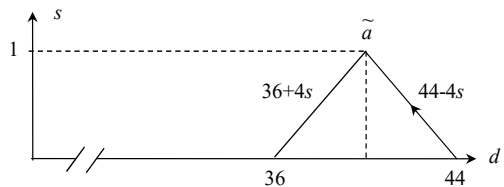

Źródło: opracowanie własne. b)

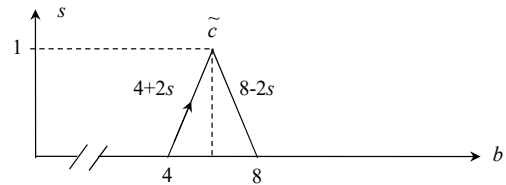

RYSUNEK 6.

Skierowane liczby rozmyte reprezentujące współczynnik kierunkowy rozmytej liniowej funkcji: a) popytu (10), b) podaży (11)

a)

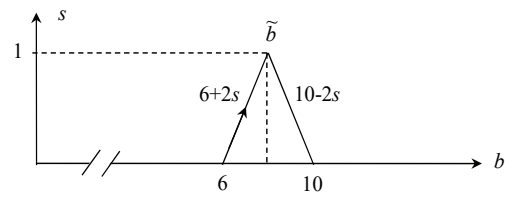

b)

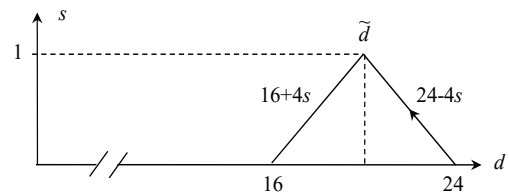

Źródło: opracowanie własne.

\section{Przykład rozmytego liniowego modelu równowagi rynkowej o współczynnikach reprezentowanych za pomocą OFN}

Rozważmy rozmyty liniowy model równowagi rynkowej o współczynnikach reprezentowanych za pomocą trójkątnych skierowanych liczb rozmytych. Przyjmijmy, że rozmyte liniowe funkcje popytu (10) oraz podaż (11) mają postać:

$$
\begin{gathered}
Q_{d}=\widetilde{40}-\tilde{8} P, \\
Q_{s}=-\tilde{6}+\widetilde{20} P .
\end{gathered}
$$

Rozważmy trzy przypadki rozmywania parametrów modelu:

a) rozmyte wyrazy wolne funkcji (16) i (17),

b) rozmyte współczynniki kierunkowe funkcji (16) i (17),

c) rozmyte parametry funkcji (16) i (17).

AD a) Rozmyty liniowy model równowagi rynkowej o rozmytych wyrazach wolnych. Funkcje (16) i (17) przyjmują wówczas postać:

$$
\begin{gathered}
Q_{d}=(44-4 s, 36+4 s)-(8,8) P, \\
Q_{s}=-(4+2 s, 8-2 s)+(20,20) P,
\end{gathered}
$$

gdzie $s \in[0,1]$. Rozmyta równowaga rynkowa ma miejsce, zgodnie z (14), gdy cena ma postać: 


$$
\bar{P}=\frac{(44-4 s, 36+4 s)+(4+2 s, 8-2 s)}{(8,8)+(20,20)}=\left(\frac{48-2 s}{28}, \frac{44+2 s}{28}\right),
$$

a odpowiadająca jej wielkość równowagi $\bar{Q}$, zgodnie z (15), ma postać:

$$
\bar{Q}=\frac{(44-4 s, 36+4 s)(20,20)-(8,8)(4+2 s, 8-2 s)}{(8,8)+(20,20)}=\left(\frac{848-96 s}{28}, \frac{656+96 s}{28}\right),
$$

gdzie $s \in[0,1]$. Na rysunku 7. pokazano obszar rozmytej równowagi rynkowej dla funkcji popytu (18) i podaży (19). Natomiast na rysunku 8a zobrazowano skierowaną liczbę rozmytą reprezentującą cenę równowagi (20), a na rysunku 8b odpowiadająca jej wielkość równowagi (21).

RYSUNEK 7.

Ilustracja graficzna rozmytej równowagi rynkowej dla funkcji popytu (18) i funkcji podaży (19)

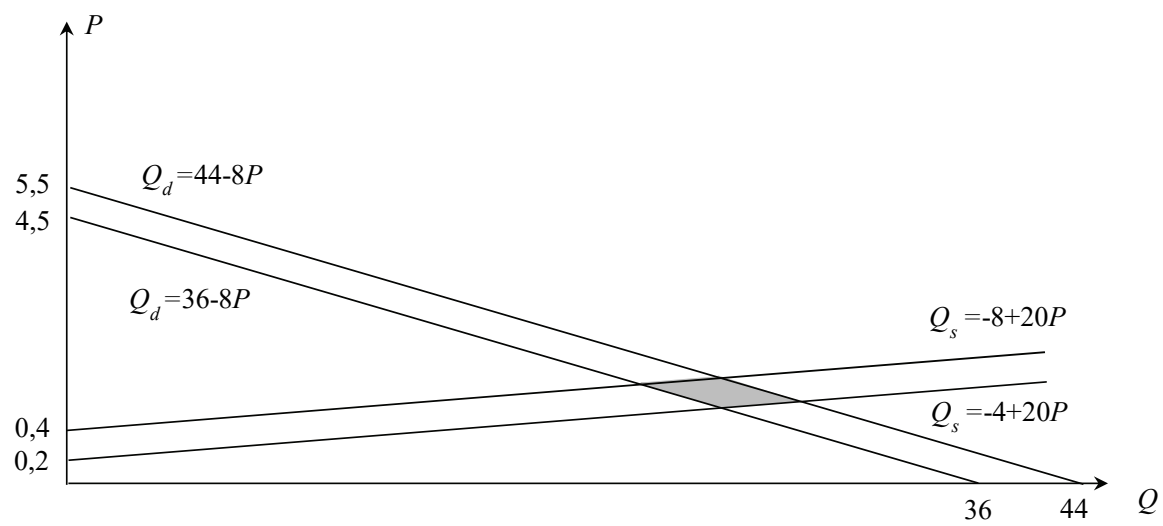

Źródło: opracowanie własne.

RYSUNEK 8.

Skierowane liczby rozmyte reprezentujące równowagę rynkową: a) cenę $\bar{P}$ (20), b) wielkość równowagi $\bar{Q}(21)$

a)

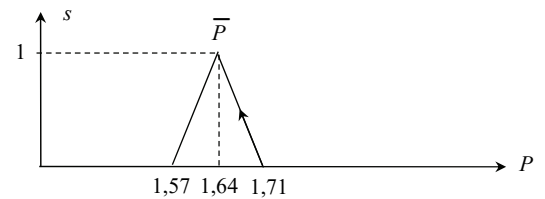

b)

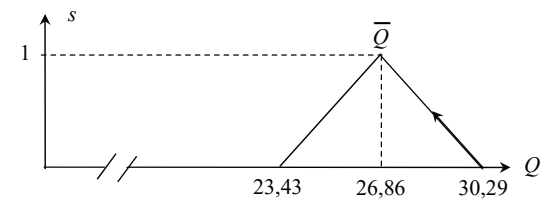

Źródło: opracowanie własne.

AD b) Liniowy rozmyty model równowagi rynkowej o rozmytych współczynnikach kierunkowych. Funkcje (16) i (17) przyjmują wówczas postać:

$$
\begin{aligned}
& Q_{d}=(40,40)-(6+2 s, 10-2 s) P, \\
& Q_{s}=-(6,6)+(24-4 s, 16+4 s) P,
\end{aligned}
$$


gdzie $s \in[0,1]$. Rozmyta równowaga rynkowa ma miejsce, gdy cena ma postać:

$$
\bar{P}=\frac{(40,40)+(6,6)}{(6+2 s, 10-2 s)+(24-4 s, 16+4 s)}=\left(\frac{46}{30-2 s}, \frac{46}{26+2 s}\right),
$$

a odpowiadająca jej wielkość równowagi $\bar{Q}$ jest postaci:

$$
\bar{Q}=\frac{(40,40)(24-4 s, 16+4 s)-(6,6)(6+2 s, 10-2 s)}{(6+2 s, 10-2 s)+(24-4 s, 16+4 s)}=\left(\frac{924-172 s}{30-2 s}, \frac{580+172 s}{26+2 s}\right),
$$

gdzie $s \in[0,1]$. Na rysunku 9. pokazano obszar rozmytej równowagi rynkowej dla funkcji popytu (22) i podaży (23). Natomiast na rysunku 10a zobrazowano skierowaną liczbę rozmytą reprezentująca cenę równowagi (24), a na rysunku 10b odpowiadającą jej wielkość równowagi (25).

RYSUNEK 9.

Ilustracja graficzna rozmytej równowagi rynkowej dla funkcji popytu (22) i funkcji podaży (23)

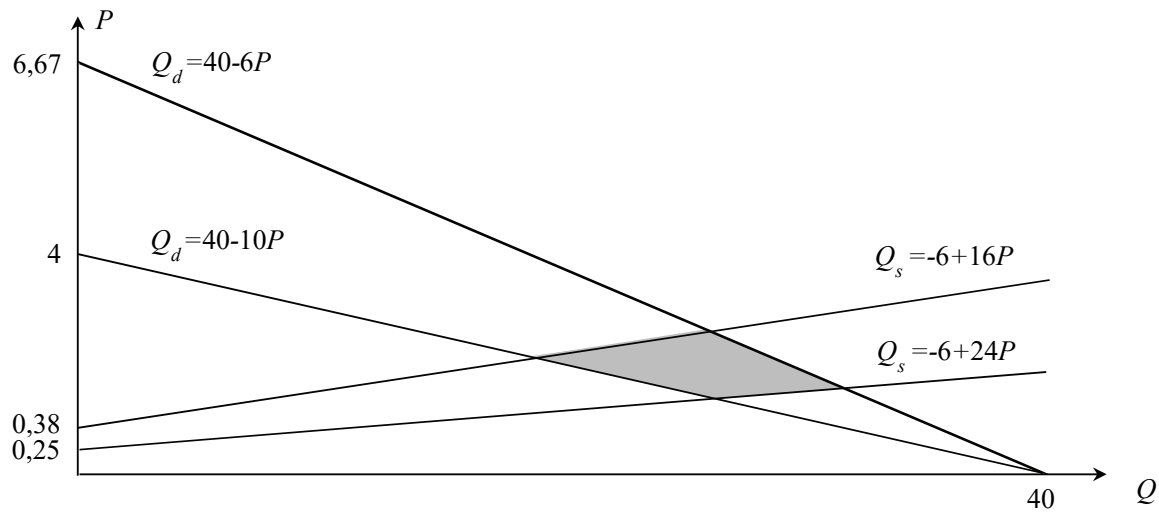

Źródło: opracowanie własne.

RYSUNEK 10.

Skierowane liczby rozmyte reprezentujące równowagę rynkową: a) cenę $\bar{P}$ $(24)$, b) wielkość równowagi $\bar{Q}(25)$

a)

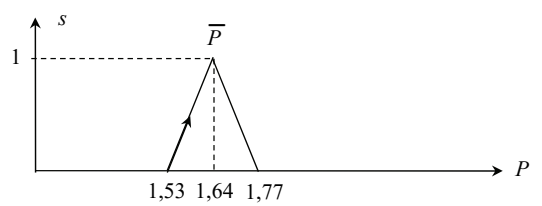

b)

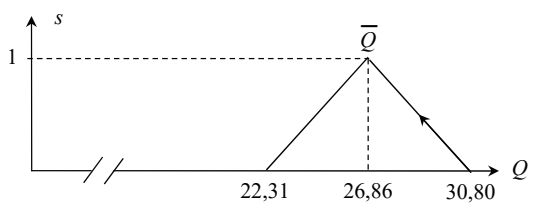

Źródło: opracowanie własne. 
AD c) Liniowy rozmyty model równowagi rynkowej o rozmytych parametrach. Funkcje (16) i (17) przyjmują wówczas postać:

$$
\begin{aligned}
& Q_{d}=(44-4 s, 36+4 s)-(6+2 s, 10-2 s) P, \\
& Q_{s}=-(4+2 s, 8-2 s)+(24-4 s, 16+4 s) P,
\end{aligned}
$$

gdzie $s \in[0,1]$. Rozmyta równowaga rynkowa ma miejsce, gdy cena ma postać:

$$
\bar{P}=\frac{(44-4 s, 36+4 s)+(4+2 s, 8-2 s)}{(6+2 s, 10-2 s)+(24-4 s, 16+4 s)}=\left(\frac{48-2 s}{30-2 s}, \frac{44+2 s}{26+2 s}\right),
$$

a odpowiadająca jej wielkość równowagi $\bar{Q}$ jest postaci:

$$
\begin{aligned}
\bar{Q}= & \frac{(44-4 s, 36+4 s)(24-4 s, 16+4 s)-(6+2 s, 10-2 s)(4+2 s, 8-2 s)}{(6+2 s, 10-2 s)+(24-4 s, 16+4 s)}= \\
= & \left(\frac{12 s^{2}-292 s+1032}{30-2 s}, \frac{12 s^{2}+244 s+496}{26+2 s}\right),
\end{aligned}
$$

gdzie $s \in[0,1]$. Na rysunku 11. pokazano obszar rozmytej równowagi rynkowej dla funkcji popytu (26) i podaży (27). Natomiast na rysunku 12a zobrazowano skierowana liczbę rozmytą reprezentującą cenę równowagi (28), a na rysunku 12 b odpowiadająca jej wielkość równowagi (29).

RYSUNEK 11.

Ilustracja graficzna rozmytej równowagi rynkowej dla funkcji popytu (22) i funkcji podaży (23)

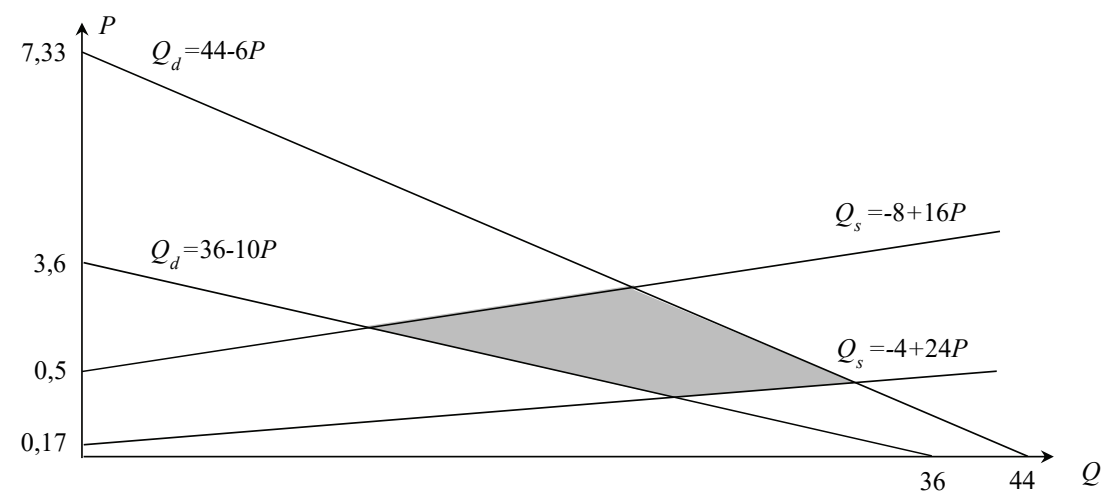

Źródło: opracowanie własne. 
RYSUNEK 12.

\section{Skierowane liczby rozmyte reprezentujące równowagę rynkową: a) cenę $\bar{P}$} (28), b) wielkość równowagi $\bar{Q}(29)$

a)

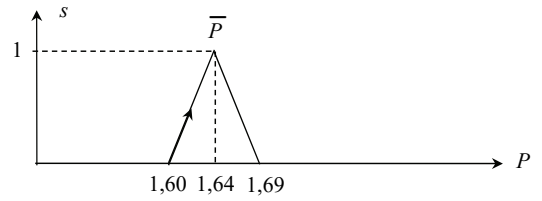

b)

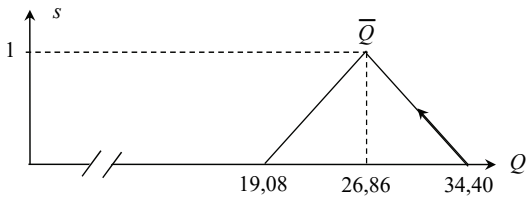

Źródło: opracowanie własne.

\section{Podsumowanie}

W pracy przedstawiono modyfikację liniowego modelu (częściowej) równowagi rynkowej, w którym parametry, zazwyczaj opisywane liczbami rzeczywistymi, zastapiono skierowanymi liczbami rozmytymi. Umożliwia to reprezentowanie równowagi rynkowej za pomoca pewnego podzbioru płaszczyzny (płaszczyzny ceny i odpowiadającej jej wielkości popytu/podaży), a nie za pomoca punktu. Powoduje to, że model wierniej odzwierciedla rzeczywistość gospodarcza, ponieważ punktowe położenie równowagi jest raczej stanem idealnym i trudnym do osiagnięcia w realnych warunkach ekonomicznych. Co więcej, skierowane liczby rozmyte pozwalają uwzględniać dodatkowy czynnik, np. oczekiwania konsumenta czy producenta, obrazowany skierowaniem.

\section{Literatura}

Chiang A.C., 1994, Podstawy ekonomii matematycznej, Polskie Wydawnictwo Ekonomiczne, Warszawa.

Dubois D., Prade H., 1980, Fuzzy Sets and Systems: Theory and Application, Academic Press, New York.

Gawinecki J., 2000, Matematyka dla ekonomistów, Wydawnictwo Wyższej Szkoły Handlu i Prawa, Warszawa.

Kacprzak D., 2008, Model Leontiewa i skierowane liczby rozmyte, VII Konferencja Naukowo-Praktyczna „Energia w nauce i technice”, Wydawnictwo Politechniki Białostockiej, Suwałki.

Kacprzak D., 2010, Skierowane liczby rozmyte w modelowaniu ekonomicznych, „Optimum. Studia Ekonomiczne", nr 3.

Kacprzak D., 2012a, Przychód i koszt catkowity przedsiębiorstwa wyrażony przy u̇̇yciu skierowanych liczb rozmytych, „Zarządzanie i Finanse. Journal of Management and Finance”, no. $2 / 1$. 
Kacprzak D., 2012b, Zastosowanie skierowanych liczb rozmytych do prezentacji cen ak.cji, „Optimum. Studia Ekonomiczne", nr 6.

Kacprzak D., 2014, Prezentacja cen dóbr konsumpcyjnych oraz dynamiki ich zmian za pomoca skierowanych liczb rozmytych, „Optimum. Studia Ekonomiczne”, nr 1.

Kacprzak D., 2017, Objective Weights Based on Ordered Fuzzy Numbers for Fuzay Multiple Criteria Decision Making Methods, "Entropy", 19(7), 373.

Kacprzak D., 2017, The Input-Output Model Based on Ordered Fuzay Numbers, [in:] Theory and Applications of Ordered Fuzzy Numbers: A Tribute to Professor Witold Kosinski, P. Prokopowicz, J. Czerniak, D. Mikołajewski, Ł. Apiecionek, D. Ślęzak (eds.), "Studies in Fuzziness and Soft Computing”, vol. 356, Springer.

Kacprzak D., Kosiński W., 2014, Optimizing firm inventory costs as a fuzzy problem, "Studies in Logic, Grammar and Rhetoric", nr 37.

Kacprzak D., Kosiński W., Kosiński W. K., 2013, Financial stock data and ordered fuzzy numbers, Artificial Intelligence and Soft Computing: 12th International Conference, ICAISC'2013, Berlin.

Kosiński W., Prokopowicz P., 2004, Algebra liç̧b rozmytych, „Matematyka Stosowana”, nr 5(46).

Kosiński W., Prokopowicz P., Kacprzak D., 2009, Fuzziness - representation of dynamic changes by ordered fuz:y numbers, Studies in Fuzziness and Soft Computing, 243, SpringerVerlag, Berlin.

Kosiński W., Prokopowicz P., Ślęzak D., 2002, Drawback of fuzzy arthmetics - new intutions and propositions, [in:] Methods of Aritificial Intelligence, T. Burczyński, W. Cholewa, W. Moczulski (eds.), Gliwice.

Kosiński W., Prokopowicz P., Ślęzak D., 2003, Ordered Furzy Numbers, "Bulletin of the Polish Academy of Sciences Mathematic", 52(3).

Marszałek A., Burczyński T., 2013, Financial fuzzy time series models based on ordered fuzzy numbers, [in:] Time Series Analysis. Modelling and Applications, W. Pedrycz, S. M. Chen (eds.), ISRL 47, Springer, Berlin, Heidelberg.

Milewski R., Kwiatkowski E., 2005, Podstawy ekonomii, Wydawnictwo Naukowe PWN, Warszawa.

Prokopowicz P., Pedrycz W., 2015, The Directed Compatibility Between Ordered Fuz:y Numbers - A Base Tool for a Direction Sensitive Fuzzy Information Processing, "Artificial Intelligence and Soft Computing", vol. 9119.

Roszkowska E., Kacprzak D., 2016, The fuzzy SAW and fuzzy TOPSIS procedures based on ordered fuzay numbers, "Information Sciences", vol. 369.

Rudnik K., Kacprzak D., 2017, Fuz氵y TOPSIS method with ordered fuzay numbers for flow control in a manufacturing system, "Applied Soft Computing", vol. 52.

Sloman J., 2001, Podstawy ekonomii, Polskie Wydawnictwo Ekonomiczne, Warszawa.

Sobol I., Kacprzak D., Kosiński W., 2015, Optimizing of a company's costs under fuzzy data and optimal orders under dynamic conditions, "Optimum. Studia Ekonomiczne", nr 5.

Zadeh L.A., 1965, Furzy Sets, "Inforsmation and Control", no. 8. 